\title{
PENGARUH BENZILADENIN DAN VITAMIN B TERHADAP PERTUMBUHAN BIBIT ANGGREK DENDROBIUM
}

\author{
Dea Resty Noventa, Sri Ramadiana, Rugayah \& Yusnita \\ Jurusan Agroteknologi, Fakultas Pertanian Universitas Lampung \\ Jl. Prof. Dr. Soemantri Brodjonegoro no. 1 Bandar Lampung 35145 \\ Email: diary_venta@yahoo.com
}

\begin{abstract}
ABSTRAK
Dendrobium adalah salah satu anggrek epifit yang banyak diminati oleh masyarakat. Permintaan anggrek Dendrobium semakin meningkat setiap tahunnya, akan tetapi anggrek memiliki tipe pertumbuhan yang lambat sehingga untuk membantu pertumbuhan dan perkembangannya, anggrek membutuhkan zat pengatur tumbuh. Selain itu, anggrek juga membutuhkan vitamin sebagai katalisator dalam proses metabolisme. Penelitian ini bertujuan untuk mengetahui pengaruh peningkatan konsentrasi benziladenin terhadap pertumbuhan bibit anggrek Dendrobium yang berasal dari bibit botolan, pemberian vitamin B terhadap pertumbuhan bibit anggrek Dendrobium yang berasal dari bibit botolan, dan ada atau tidaknya interaksi antara peningkatan konsentrasi benziladenin dan vitamin B terhadap pertumbuhan anggrek Dendrobium. Penelitian dilaksanakan di rumah kaca Fakultas Pertanian Universitas Lampung dari bulan Maret sampai September 2013. Penelitian ini menggunakan Rancangan Acak Lengkap (RAL). Perlakuan disusun secara faktorial (3x2). Faktor pertama adalah konsentrasi BA 20; 40; dan 60 mg/l dan faktor kedua adalah vitamin B $0 \mathrm{~g} / \mathrm{l}$ (tanpa vitamin B) dan vitamin B $1 \mathrm{~g} / \mathrm{l}$. Setiap kombinasi perlakuan diulang tiga kali dan masing-masing percobaan terdiri dari 10 bibit anggrek Dendrobium dengan sampel percobaan 5 bibit tanaman. Homogenitas ragam antar perlakuan diuji dengan uji Bartlett. Apabila kedua asumsi terpenuhi dilanjutkan dengan analisis ragam dilanjutkan dengan uji BNT pada taraf 5\%. Hasil penelitian menunjukkan bahwa penggunaan BA $20 \mathrm{mg} / \mathrm{l}$ menghasilkan pertumbuhan terbaik tanaman jika dibandingkan dengan BA 40 dan $60 \mathrm{mg} / \mathrm{l}$. Penambahan vitamin B $1 \mathrm{~g} / \mathrm{l}$ tidak menunjukkan pertumbuhan yang lebih baik jika dibandingkan dengan tanpa vitamin B. Interaksi terbaik didapat pada perlakuan BA $20 \mathrm{mg} / \mathrm{l} \mathrm{dengan} \mathrm{tanpa}$ vitamin B, yaitu pada variabel pengamatan penambahan tinggi tanaman, jumlah akar, panjang akar, dan bobot basah.
\end{abstract}

Kata kunci: Benziladenin, Dendrobium, Vitamin B.

\section{PENDAHULUAN}

Anggrek Dendrobium merupakan tanaman anggrek dengan genus terbesar yang berasal dari famili Orchidaceae, anggrek ini diperkirakan mempunyai 1200 spesies, Dendrobium pertama kali ditemukan oleh Olaf Swartz di tahun 1974 (Puchooa, 2004). Indonesia merupakan negara yang terletak di garis khatulistiwa sehingga memiliki iklim tropis, selain itu keadaan di Indonesia sesuai dengan photoperiodity atau lamanya masa penyinaran matahari sehari-hari yang dibutuhkan oleh Dendrobium, kondisi ini sangat menguntungkan (Sutiyoso, 2003). Menurut data yang diperoleh dari Direktorat Tanaman Hias (2004), produksi anggrek meningkat sebanyak 25\% yaitu dari 75.192 .000 tangkai dan 16.166.628 pot di tahun 2005 menjadi 89.692.000 tangkai dan 19.284.219 pot di tahun 2010. Namun walaupun pada kenyataannya produksi anggrek meningkat, volume impor anggrek Dendrobium hibrida baru dari Taiwan dan Thailand masih tinggi. Hal tersebut mencerminkan bahwa daya saing penganggrek dari Indonesia lemah. Salah satu penyebabnya adalah rendahnya penyediaan bibit anggrek bermutu dalam skala yang besar (Ramadiana et al., 2008).

Umumnya anggrek Dendrobium yang bersifat epifit mempunyai akar yang lunak dan mudah patah. Setelah ditanam pada media baru, maka akar tua yang berasal dari planlet akan menjadi coklat dan kering, kemudian akan digantikan fungsinya oleh akar-akar yang baru tumbuh (Gunawan, 2004). Pertumbuhan akar dapat dirangsang dengan penambahan vitamin yang penting untuk metabolisme tumbuhan, hal ini sesuai dengan hasil penelitian Budiarti (2010) yang melaporkan bahwa bibit anggrek Dendrobium umur 2 bulan setelah tanam yang diberi perlakuan vitamin $\mathrm{B}_{1}$ menghasilkan pertambahan jumlah akar terbanyak jika dibandingkan pemberian BA $10 \mathrm{mg} / \mathrm{l}$ dan kontrol (tanpa perlakuan). Penambahan thiamin dengan konsentrasi rendah $(0,1$ ppm) mampu memacu pertumbuhan dan perkembangan biji Dendrobium laxiflorum pada fase 2 tanaman, 
dimana biji anggrek tumbuh dan berkembang menjadi protocorm dengan primordium daun (Amalia et al., 2013). Vitamin berperan dalam proses pertumbuhan sebagai katalisator dalam proses metabolisme. Vitamin yang paling sering digunakan dalan kultur in vitro antara lain thiamin (vitamin $\mathrm{B}_{1}$ ), asam nikotinat (vitamin $\mathrm{B}_{3}$ ) dan piridoksin (vitamin $\mathrm{B}_{6}$ ) (Widiastoety et al., 2009).

Selain membutuhkan vitamin, jenis dan jumlah zat pengatur tumbuh salah satunya yaitu benziladenin (BA) dianggap mampu meningkatkan pertumbuhan tanaman anggrek Dendrobium. Pada media kultur jaringan, semua perbanyakan tunas dirangsang oleh sitokinin benziladenin (BA). Zat pengatur tumbuh benziladenin (BA) tidak hanya digunakan pada media kultur jaringan, penggunaan zat pengatur tumbuh benziladenin (BA) pada saat aklimatisasi juga dapat memacu pertumbuhan bibit secara signifikan, yang ditunjukkan dengan pertambahan bobot dan ukuran tanaman (Yusnita, 2010). Hasil penelitian Utama (2011) menunjukkan pemberian BA 10-15 mg/l akan meningkatkan tinggi tunas, jumlah tunas, dan bobot basah anggrek Dendrobium hibrida. Hasil penelitian lain (Budiarti, 2010) juga menunjukkan bahwa penggunaan benziladenin (BA) dengan dosis $10 \mathrm{mg} / \mathrm{l}$, terbukti mampu meningkatkan bobot tanaman, jumlah tunas, dan jumlah daun anggrek Dendrobium pada usia dua bulan setelah tanam.

Tujuan penelitian ini adalah untuk mengetahui konsentrasi benziladenin terbaik dan pengaruh vitamin B terhadap pertumbuhan bibit anggrek Dendrobium yang berasal dari botolan.

\section{BAHAN DAN METODE}

Penelitian ini dilaksanakan di Rumah Kaca Fakultas Pertanian Universitas Lampung dari bulan Maret sampai dengan September 2013. Alat dan bahan yang digunakan dalam penelitian ini adalah pot plastik dengan diameter $10 \mathrm{~cm}$; hand sprayer; timbangan; penggaris; kertas label; dan alat tulis. Bahan tanaman berasal dari anggrek botolan hasil kultur jaringan anggrek Dendrobium Metallica, $\mathrm{P}_{9} \mathrm{P}_{7}, \mathrm{P}_{2 x}$, yang berumur 6 bulan setelah aklimatisasi; pupuk daun GrowMore (32:10:10); vitamin $B$ dengan kandungan: vitamin $B_{1} 2 \mathrm{mg}$, vitamin $\mathrm{B}_{2} 2 \mathrm{mg}$, vitamin $\mathrm{B}_{6} 2 \mathrm{mg}$, vitamin $\mathrm{B}_{12} 2 \mathrm{mg}$, calcium panthothenate $10 \mathrm{mg}$, nicotinadium $20 \mathrm{mg}$; benziladenin (BA) dengan taraf konsentrasi 20, 40, 60 mg/l; Dithane M-45 (b.a Mankozeb $80 \%$ ); Furadan 3g (b.a karbofuran 3\%); cacahan pakis; potongan sterofoam dengan ukuran $2 \times 2 \mathrm{~cm}$; dan sabut kelapa. Penelitian ini dilakukan dalam rancangan acak lengkap, dengan perlakuan yang disusun secara faktorial, dengan menggunakan tiga ulangan untuk setiap kombinasi perlakuan dan di dalam satu ulangan terdapat sepuluh tanaman dengan sampel lima tanaman anggrek. Faktor pertama adalah benziladenin (BA) dengan konsentrasi 20, 40 dan $60 \mathrm{mg} /$ liter dan faktor kedua adalah vitamin B dengan konsentrasi 0 dan 1 gram/liter. Homogenitas ragam antar perlakuan diuji dengan Uji Bartlett. Bila kedua asumsi terpenuhi, maka analisis data dilanjutkan dengan sidik ragam. Pemisahan nilai tengah dilakukan dengan beda nyata terkecil (BNT) pada taraf 5\%.

Variabel pengamatan adalah penambahan tinggi tanaman, penambahan panjang akar, penambahan jumlah akar, penambahan bobot basah, dan tingkat kehijauan daun.

\section{HASIL DAN PEMBAHASAN}

Hasil percobaan menunjukkan bahwa pemberian BA dan vitamin B mampu meningkatkan pertumbuhan tanaman anggrek Dendrobium pada masa pembesaran. Respon pertumbuhan tanaman terlihat dari hasil rekapitulasi analisis ragam (Tabel 1), pemberian BA berpengaruh terhadap rata-rata penambahan tinggi tanaman, rata-rata penambahan panjang akar, rata-rata penambahan jumlah akar, rata-rata penambahan bobot tanaman, dan rata-rata tingkat kehijauan daun,. Sedangkan perlakuan tanpa pemberian vitamin B berpengaruh terhadap rata-rata penambahan tinggi

Tabel 1. Rekapitulasi hasil analisis ragam pengaruh pemberian BA dan vitamin B pada pembesaran bibit anggrek Dendrobium setelah 6 bulan aplikasi.

\begin{tabular}{lccc}
\hline \multicolumn{1}{c}{ Variabel Pengamatan } & Konsentrasi BA & Konsentrasi Vit. B & Vitamin B x BA \\
\hline Rata-rata penambahan tinggi tanaman & $*$ & $*$ & $*$ \\
Rata-rata penambahan panjang akar & $*$ & $*$ & $*$ \\
Rata-rata penambahan jumlah akar & $*$ & tn & $*$ \\
Rata-rata penambahan bobot tanaman & $*$ & $*$ & $*$ \\
Rata-rata tingkat kehijauan daun & $*$ & tn & $*$ \\
\hline
\end{tabular}


tanaman, rata-rata penambahan panjang akar, rata-rata penambahan jumlah akar, dan rata-rata penambahan bobot tanaman. Interaksi antara perlakuan BA dan tanpa vitamin B berpengaruh terhadap rata-rata penambahan tinggi tanaman, rata-rata penambahan panjang akar, rata-rata penambahan jumlah akar, ratarata penambahan bobot tanaman, dan rata-rata kehijauan daun (Gambar 1 dan 2).

Perlakuan BA dengan konsentrasi $20 \mathrm{mg} / \mathrm{l}$ dan tanpa vitamin B berpengaruh terhadap 4 variabel pengamatan, yaitu penambahan jumlah akar, bobot basah, tinggi tanaman, dan panjang akar. BA $40 \mathrm{mg} / \mathrm{l}$ dan tanpa vitamin B berpengaruh meningkatkan ratarata kehijauan daun, sedangkan BA $60 \mathrm{mg} / \mathrm{l}$ tanpa vitamin
B dan dengan vitamin B tidak menunjukkan pengaruh dalam meningkatkan pertumbuhan tanaman. Aplikasi BA pada konsentrasi $20 \mathrm{mg} / \mathrm{l}$ menunjukkan hasil pertumbuhan yang lebih baik pada variabel pengamatan jumlah akar, bobot basah, tinggi tanaman dan panjang akar, hasil penelitian Zasari (2010) menunjukkan bahwa penggunaan BA $20 \mathrm{mg} / 1$ mampu meningkatkan pertumbuhan tanaman anggrek Dendrobium hibrida yang berusia 10 bulan setelah tanam (in vitro), khususnya pada variabel pengamatan tinggi tanaman, jumlah daun, jumlah akar, dan bobot basah.

Pada konsentrasi BA $40 \mathrm{mg} / \mathrm{l}$ memperlihatkan pertumbuhan yang lebih baik pada variabel pengamatan rata-rata kehijauan daun. Menurut Thomas dan
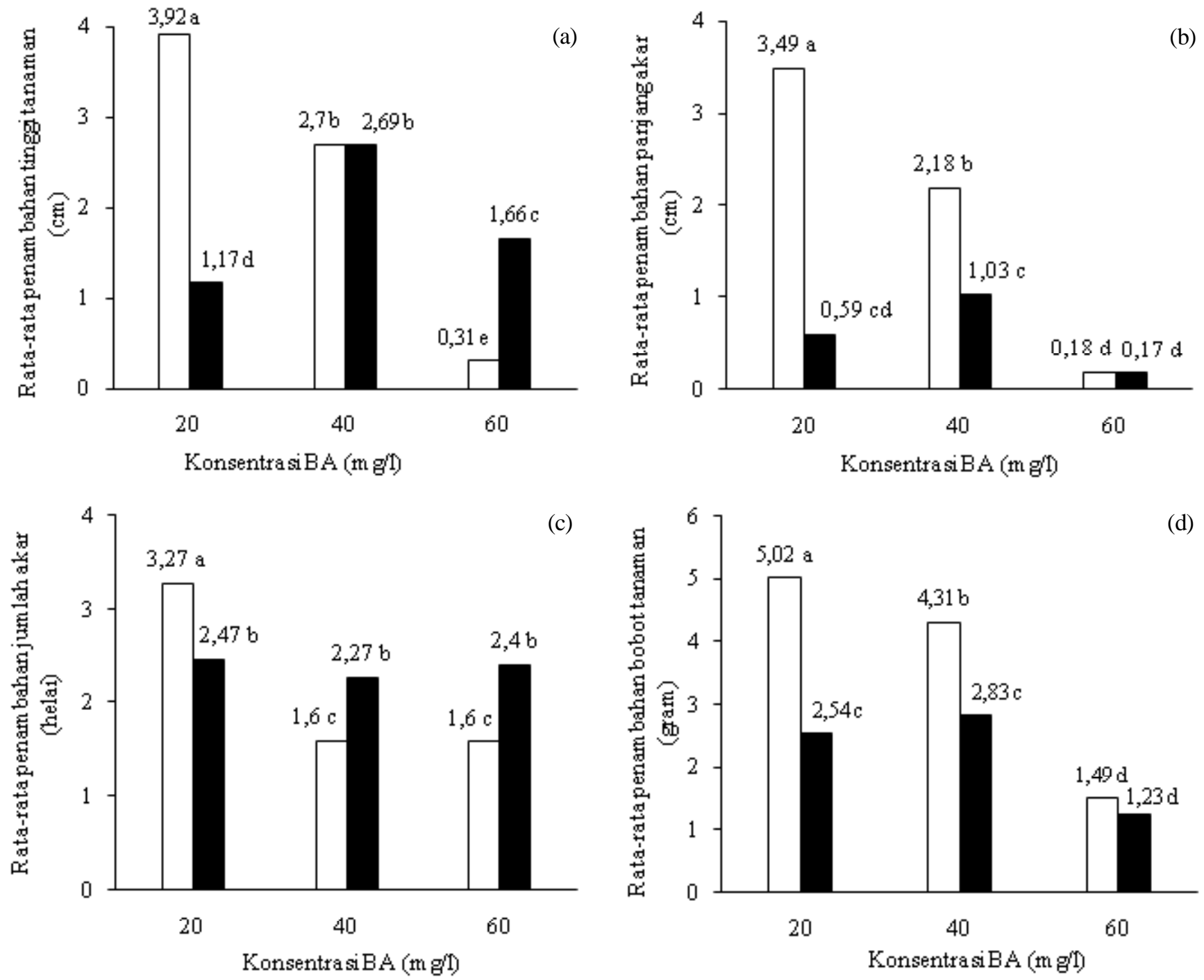

Gambar 1. Pengaruh pemberian BA dan vitamin B terhadap penambahan (a) tinggi tanaman, (b) panjang akar, (c) jumlah akar, (d) bobot basah, anggrek Dendrobium setelah 6 bulan aplikasi. Dua nilai tengah yang diikuti huruf yang sama dinyatakan tidak berbeda nyata menurut uji BNT pada taraf $5 \%=0,49$. 


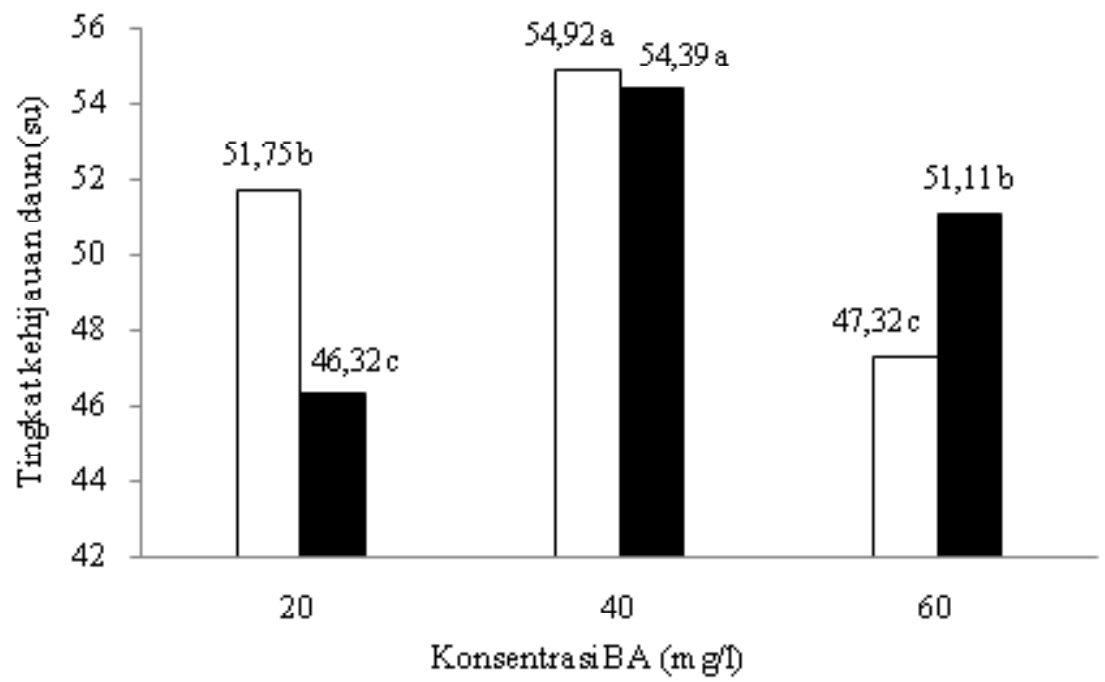

Gambar 2. Pengaruh pemberian BA dan vitamin B terhadap tingkat kehijauan daun anggrek Dendrobium setelah 6 bulan aplikasi. Dua nilai tengah yang diikuti huruf yang sama dinyatakan tidak berbeda nyata menurut uji BNT pada taraf $5 \%=2,29$.

Blakesley (1987) dalam Fuadi dan Hilman (2008) benziladenin yang memiliki bahan aktif sitokinin sintetik apabila diaplikasikan pada daun dapat merangsang diferensiasi klorofil dan sintesis klorofil yang mampu menghambat penuaan, menghambat rontok daun, menghambat degradasi protein, dan meningkatkan diferensiasi vascular. Fuadi dan Hilman (2008) melaporkan bahwa pemberian BA pada Dracaena sanderiana dengan konsentrasi BA $300 \mathrm{mg} / \mathrm{l}$ menghasilkan kandungan klorofil yang sangat baik dan Codiaeum variegatum menghasilkan kandungan klorofil terbaik pada pemberian BA $150 \mathrm{mg} / \mathrm{l}$. Pada percobaan ini konsentrasi BA $40 \mathrm{mg} / \mathrm{l}$ sudah berpengaruh terhadap rata-rata kehijauan daun, hal tersebut mungkin disebabkan oleh beberapa faktor seperti usia tanaman, jenis tanaman dan ukuran tanaman. Pemberian zat pengatur tumbuh dengan konsentrasi yang tepat mampu mempengaruhi pertumbuhan dan perkembangan tanaman (George, 2008).

Perlakuan tanpa vitamin B pada berbagai konsentrasi BA (20, 40, dan $60 \mathrm{mg} / \mathrm{l})$ memberikan hasil yang terbaik untuk variabel pengamatan rata-rata penambahan tinggi tanaman, bobot basah, jumlah akar dan panjang akar tanaman anggrek Dendrobium. Pada konsentrasi BA yang lebih tinggi $40 \mathrm{mg} / \mathrm{l}$ tanpa vitamin $\mathrm{B}$, hasilnya terlihat lebih baik pada variabel pengamatan rata-rata tingkat kehijauan daun. Aplikasi konsentrasi BA $60 \mathrm{mg} / \mathrm{l}$ tanpa vitamin B menghasilkan rata-rata terendah dibandingkan dengan aplikasi BA 20 dan 40 $\mathrm{mg} / \mathrm{l}$.
Vitamin B yang diaplikasikan ke tanaman anggrek Dendrobium yang berusia 6 bulan setelah aklimatisasi terlihat menekan pertumbuhan tanaman. Hal tersebut dapat dilihat dari beberapa variabel utama yang diukur, seperti bobot basah, tinggi tanaman, dan jumlah akar. Hasil ini bertolak belakang dengan penelitian terdahulu Budiarti (2010), pemberian vitamin $\mathrm{B}_{1}$ dengan dosis 3 ml larutan/tanaman, kandungan $\mathrm{P}_{2} \mathrm{O}_{5} 2,0 \%$, iron $(\mathrm{Fe})$ $0,10 \%$, vitamin $\mathrm{B} 1$ (thiamine mononitrate) $0,10 \%$, dan NAA $0,04 \%$ memberikan hasil yang baik pada aklimatisasi anggrek Dendrobium usia 4 bulan. Tertekannya pertumbuhan anggrek Dendrobium pada penelitian ini diduga karena adanya perbedaan komposisi vitamin B yang digunakan. Pada penelitian ini komposisi vitamin $\mathrm{B} /$ tablet $(0,80 \mathrm{~g})$ yang digunakan adalah vitamin $\mathrm{B}_{1} 2 \mathrm{mg}$, vitamin $\mathrm{B}_{2} 2 \mathrm{mg}$, vitamin $\mathrm{B}_{6} 2 \mathrm{mg}$, vitamin $\mathrm{B}_{12}$ $2 \mathrm{mg}$, calcium panthothenate $10 \mathrm{mg}$, dan nicotinadium $20 \mathrm{mg}$.

Dugaan penulis adalah kemungkinan banyaknya komposisi vitamin B yang digunakan dan bahan adenda lain dapat berpengaruh terhadap pertumbuhan anggrek Dendrobium, sehingga tanaman anggrek yang tidak diberi perlakuan vitamin B tampak lebih baik pertumbuhannya dibandingkan dengan tanaman anggrek yang tidak diberikan vitamin $B$.

\section{KESIMPULAN}

Pemberian BA dengan konsentrasi $20 \mathrm{mg} / \mathrm{l}$ menghasilkan pertumbuhan yang terbaik untuk anggrek 
Dendrobium, yang ditunjukkan oleh variabel bobot basah, tinggi tanaman, dan jumlah akar. Perlakuan tanpa vitamin B menghasilkan pertumbuhan tanaman anggrek Dendrobium yang lebih baik dibandingkan dengan pemberian vitamin B yang ditunjukkan oleh variabel tinggi tanaman, jumlah akar, bobot basah, dan kehijauan daun. Kombinasi terbaik adalah pemberian BA $20 \mathrm{mg} / \mathrm{l}$ tanpa vitamin B dalam mempengaruhi pertumbuhan tanaman anggrek Dendrobium untuk variabel pengamatan tinggi tanaman, panjang akar, jumlah akar, dan bobot basah.

\section{DAFTAR PUSTAKA}

Amalia. R., T. Nurhidayati dan S. Nurfadilah. 2013. Pengaruh jenis dan konsentrasi vitamin terhadap pertumbuhan dan perkembangan biji Dendrobium laxiflorum J.J Smith secara in vitro. Jurnal Sains dan Seni Pomits. 1 (1) : 1-6.

Budiarti, N. 2010. Pengaruh media dan cara tanam terhadap aklimatisasi dan pengaruh benziladenin dan vitamin $b_{1}$ terhadap pertumbuhan anggrek Dendrobium. (Skripsi). Universitas Lampung. 70 hal.

Direktorat Tanaman Hias. 2004. Prospek dan arah pengembangan agribisnis anggrek. http:// www.litbang.deptan.go.id. Di akses tanggal pada tanggal : 19 November 2012.

Fuadi, M. dan Y. Hilman. 2008. Pengaruh konsentrasi benziladenin terhadap kualitas pascapanen Dracaena sanderiana dan Codiaeum variegatum. Jurnal Horti. 18(4): 457-465.
George, E.F., M.A.Hall dan G.J. De Klerk. 2008. Plant Propagation by Tissue Culture . $3^{\text {rd }}$ Edition Vol 1. Springer. Netherlands. 175 hal.

Gunawan, L. W. 2004. Budi Daya Anggrek. Penebar Swadaya. Jakarta. 90 hal.

Puchooa, D. 2004. Comparison of different culture media for the in vitro culture of dendrobium (Orchidaceae). Int. J. agri. Biol. 6 (5): 884-888.

Ramadiana, S., D. Hapsoro dan Yusnita. 2008. Upaya untuk mendapatkan tanaman anggrek Dendrobium unggul baru melalui persilangan, pengecambahan biji dan seleksi progeni serta perbanyakan klonal in vitro. Penelitian hibah bersaing perguruan tinggi XVI. Bandar Lampung.

Sutiyoso, Y. 2003. Anggrek Potong Dendrobium. Penebar Swadaya. Jakarta. 65 hal.

Utama, Y. 2011. Pengaruh benziladenin dan napthaleneacetic acid terhadap pertumbuhan anggrek Dendrobium hibrida. (Skripsi). Universitas Lampung. 58 hal.

Widiastoety, D., N. Solvia, dan S. Kartikaningrum. 2009. Pengaruh tiamin terhadap pertumbuhan planlet anggrek Oncidium secara in vitro. Jurnal Horti. 19 (1): 35-39.

Yusnita. 2010. Perbanyakan In Vitro Tanaman Anggrek. Universitas Lampung. Bandar Lampung. 128 hal.

Zasari, M. 2010. Studi perbanyakan dan regenerasi in vitro protocorm-like bodies, serta aklimatisasi planlet anggrek Dendrobium hibrida. (Tesis). Universitas Lampung. Bandar Lampung. 85 hal. 